\title{
DIVERSITY AND ECOLOGICAL TOLERANCE OF BACTERIA ISOLATED FROM THE RHIZOSPHERE OF HALOPHYTON PLANTS LIVING NEARBY KISKUNSÁG SODA PONDS, HUNGARY
}

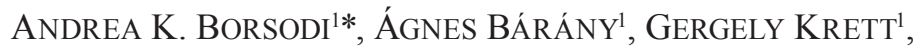 \\ KÁROly MÁRIALIGETI ${ }^{1}$ and TIBOR SzILI-KOVÁCS ${ }^{2}$ \\ ${ }^{1}$ Department of Microbiology, Eötvös Loránd University, Pázmány P. sétány 1/C, \\ H-1117 Budapest, Hungary \\ ${ }^{2}$ Institute for Soil Sciences and Agricultural Chemistry, Centre for Agricultural Research, \\ Hungarian Academy of Sciences, Herman Ottó út 15, H-1022 Budapest, Hungary
}

(Received: 23 January 2015; accepted: 3 March 2015)

\begin{abstract}
Many halophytes and halophilic microorganisms are capable to adapt to the extremities of saline habitats. This study reveals the taxonomic diversity and ecological tolerance of bacteria isolated from the rhizosphere of three different halophytes (Bolboschoenus maritimus, Puccinellia limosa and Aster tripolium) living in the vicinity of Kiskunság soda ponds. Following a sampling in September 2013, altogether 76 bacterial strains were isolated using two different media. The strains were identified on the basis of 16S rRNA gene sequencing following ARDRA grouping. Salt and $\mathrm{pH}$ tolerance of the strains were examined by measuring their growth in broths containing $0-15 \% \mathrm{NaCl}(\mathrm{w} / \mathrm{V})$ and characterized with $\mathrm{pH} 7-12$ values. Among the strains genera of Anaerobacillus, Bacillus and Exiguobacterium (Firmicutes), Agromyces, Isoptericola, Microbacterium, Micrococcus, Nocardiopsis, Nesterenkonia and Streptomyces (Actinobacteria), Halomonas and Idiomarina (Proteobacteria) and Anditalea (Bacteroidetes) were identified. The Bolboschoenus and Puccinellia samples characterized with the highest $\mathrm{pH}$ and electric conductivity values were dominated by Bacillus, Halomonas and Nesterenkonia, respectively. The salt tolerance of the bacterial strains was strongly dependent on the sampling location and plant species. In contrast, growth of bacterial strains in broths with alkaline $\mathrm{pH}$ values was more balanced. The strains from the Puccinellia sample showed the widest salt and $\mathrm{pH}$ tolerance.
\end{abstract}

Keywords: soda soil, rhizosphere bacteria, cultivation, 16S rRNA gene, $\mathrm{pH}$ and $\mathrm{NaCl}$ tolerance

* Corresponding author; E-mail: borsodi.andrea@ttk.elte.hu 


\section{Introduction}

In Europe, in addition to soda lakes, the proportion of salt affected soils (SAS) in Hungary is the highest compared to the total area (approximately 13\% of the country) [1]. The Danube-Tisza Interfluve can be characterized by Solonchak and Solonchak-Solonetz soil types which are developed on the alluvial sandy soils and classified as "Calcareous Sodic soils". In these soils sodiumcarbonate, bicarbonate, sulphate and chloride are the dominant salts. Calciumcarbonate can also be found in large quantity in the whole soil profile because of the frequent occurrence of loessial and carbonatic deposits of River Danube. The electric conductivity of the saturated soil extracts for SAS varies widely $\left(2-78 \mathrm{mS} \mathrm{cm}^{-1}\right)$, and the $\mathrm{pH}$ value is generally higher than 9.0 [1].

The vegetation shows characteristic zonation nearby the Kiskunság soda ponds. Typical plant associations develop due to the changes in topography and groundwater level which decisively influence the moisture and salinity of the upper layer of soda soils. In the salt marshes located in the shore zone of the extremely shallow soda ponds, mosaic associations are formed from homogeneous population of Bolboschoenus maritimus and mosaic plant association of Bolboschoenus-Phragmitetum. Under typical circumstances marsh vegetation is permanently water covered. "Szikfok" vegetation is characteristic in the deeper areas with repeated waterlogging away from the soda ponds. Puccinellia limosa is one of its typical endemic salt-tolerant plant species. The halophyton Aster tripolium living in soils with high salt concentration is a xero-indicator of habitats with long dry periods [2].

Studying the arbuscular mycorrhizal fungi colonization of dominant halophytes living in the Great Hungarian Plain, a characteristic seasonal dynamism was found. Mycorrhizal colonization was maximal from late spring to early summer and had a second peak later in autumn. Arbuscule formation and overall mycorrhizal colonization inversely correlated with the intensity of rainfall. It was also demonstrated that colonization depends on the plant species and their physiological status $[3,4]$. In a previous study, the community level physiological profile and genetic diversity of rhizosphere microbial communities of different plant species growing nearby Kiskunság soda ponds were compared [5]. The results suggested that geographical location, soil physical and chemical properties and the vegetation type were all important factors influencing the metabolic activity and genetic diversity of rhizosphere microbial communities [5]. 
The aim of the present study was to reveal and compare the taxonomic diversity and ecological tolerance of bacteria cultivated from the rhizosphere of three typical salt-tolerant plant species living in the vicinity of Kiskunság soda ponds.

\section{Materials and Methods}

\section{Study sites and samplings}

In each sampling site located near Böddi-szék, Kelemen-szék and Zab-szék soda ponds in the Kiskunság National Park approximately 500-500 g of rhizosphere samples from the halophyton plant species (Bolboschoenus maritimus [B16, K19, Z23], Puccinellia limosa [B17] and Aster tripolium [K21, Z24]) were collected into sterile jars in September 2013. Samples were kept cool $\left(6-8{ }^{\circ} \mathrm{C}\right)$ until laboratory processing within 24 hours. Prior to laboratory tests, roots and other visible plant residues were removed using a $2 \mathrm{~mm}$ mesh sieve.

The exact location of the sampling sites and the measured physical and chemical properties of the samples at the time of sampling are presented elsewhere [5].

\section{Cultivation and ecological tolerance testing of bacterial strains}

In order to gain insight into the abundance and species composition of rhizosphere bacterial communities, cultivation based examination was carried out using Horikoshi alkaline (DSMZ 940) and modified R2A (DSMZ 830; www. dsmz.de) media. During the laboratory work, the composition of R2A medium (DSMZ 830) was supplemented with $5.0 \mathrm{~g} \mathrm{Na}_{2} \mathrm{CO}_{3}$ and the $\mathrm{pH}$ was adjusted to 9.0.

From the composite samples produced by homogenization of equal amounts of three replicate samples, tenfold serial dilutions were made and used for plating. Following a $7-14$ day incubation period at $25^{\circ} \mathrm{C}$, the viable counts were determined, and colonies with different morphology were isolated. All isolates were purified and maintained on the isolation medium.

The $\mathrm{pH}$ range for growth was determined in a modified nutrient broth (DSMZ 1) supplemented with $50 \mathrm{~g}^{-1} \mathrm{NaCl}$, and the $\mathrm{pH}$ was adjusted to 7.0-12.0 with $\mathrm{KOH}$ at intervals of $1.0 \mathrm{pH}$ units. The salt requirement for growth was stud- 
ied in nutrient broth adjusted to $\mathrm{pH} 9.0$ and supplemented with $0,5,7,10,12$ and $15 \%(\mathrm{w} / \mathrm{v}) \mathrm{NaCl}$. Optical density change of the medium was detected at $620 \mathrm{~nm}$ after 7 days of incubation.

For the boxplot analysis of $\mathrm{NaCl}$ and $\mathrm{pH}$ tolerance results, Past Paleontological Statistics V2.08 software was applied [6].

\section{DNA extraction, ARDRA grouping and $16 S$ rRNA gene-based identification}

From each cultivated strain, a mechanical cell disruption method was applied to extract the DNA. In this procedure, a loopful of 24-48-hour slant culture was suspended in an Eppendorf tube containing $100 \mu \mathrm{l}$ of DEPC treated water and approximately $0.1 \mathrm{~g}$ of glass beads. This mixture was shaken in a Mixer Mill MM301 (Retsch, Germany) at $30 \mathrm{sec}^{-1}$ frequency for $2 \mathrm{~min}$. The obtained cell lysates were centrifuged at $10000 \mathrm{rcf}$ for $1 \mathrm{~min}$ and denatured in an Applied Biosystems Gene Amp PCR System 2700 at $98^{\circ} \mathrm{C}$ for $5 \mathrm{~min}$. The samples were then centrifuged at $10000 \mathrm{rcf}$ for $3 \mathrm{~min}$ to pellet cell debris. Supernatants were transferred to new tubes, and were used as template in polymerase chain reaction.

The 16S rRNA gene was amplified using 27f (5'-AGA GTT TGA TCM TGG CTC AG-3') and 1401r (5'-GGG TGT GTA CAA GAC CC-3') bacterial primer pair in a Gene Amp PCR System 2700 (Applied Biosystems). The PCR mixtures contained $1.5 \mathrm{mM} \mathrm{MgCl}_{2}$, the enzyme buffer, $200 \mu \mathrm{M}$ dNTPs, $0.3 \mu \mathrm{M}$ of each primer and $1 \mathrm{U}$ of Taq DNA polymerase. The following PCR temperature protocol was used: initial denaturation at $95^{\circ} \mathrm{C}$ for $3 \mathrm{~min}$, followed by 32 cycles of annealing at $52{ }^{\circ} \mathrm{C}$ for $30 \mathrm{~s}$, extension at $72^{\circ} \mathrm{C}$ for $1 \mathrm{~min}$ and denaturation at $94{ }^{\circ} \mathrm{C} 30 \mathrm{~s}$, and a final extension at $72{ }^{\circ} \mathrm{C}$ for $10 \mathrm{~min}$.

The PCR products of bacterial strains were visualized in 1\% agarose gel and grouped by ARDRA (Amplified Ribosomal DNA Restriction Analysis) method [7] using enzymes Hin6I and BsuRI (Fermentas, Vilnius, Lithuania). Each reaction contained 2.5 $\mu \mathrm{l}$ Y+/Tango Buffer (Fermentas), $15.2 \mu 1$ sterile distilled water, $3 \mathrm{U}$ of enzyme and $7 \mu \mathrm{l}$ of PCR product. Digestions were made at $37^{\circ} \mathrm{C}$, for 3 hours. Digestion products were separated in $2 \%$ agarose gels (Gibco), and visualized with UV excitation.

The identification of representative bacterial strains was based on partial 16S rRNA gene sequence analysis. The sequencing reaction using $27 \mathrm{f}$ primer was performed by the LGC Genomics (Berlin, Germany). Sequences were identified using the EzTaxon database [8]. The phylogenetic dendrograms were constructed by neighbor-joining method, using MEGA 5.0 software [9]. The accession numbers of bacterial strains are presented in the phylogenetic trees (Figs 1-3). 


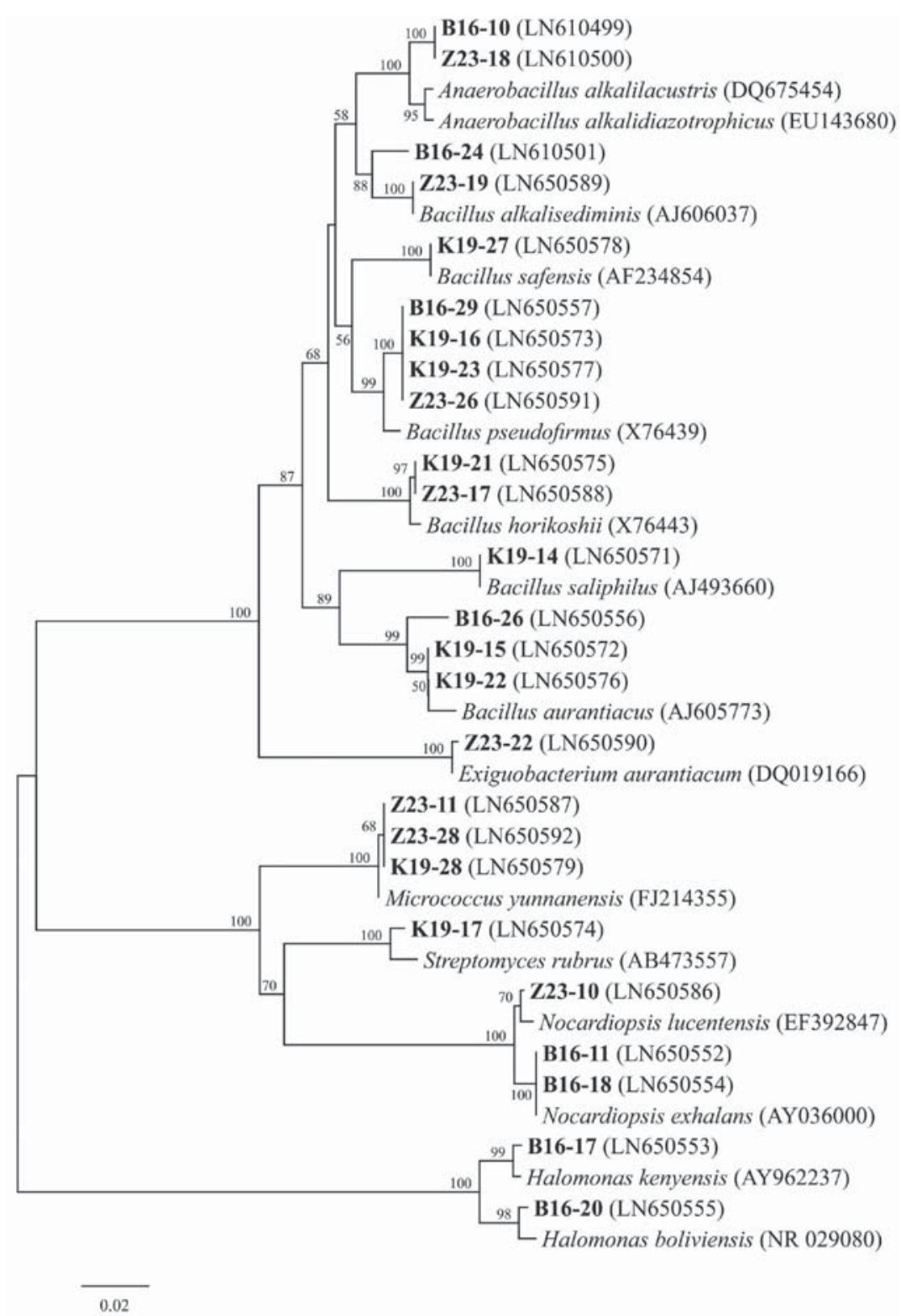

Figure 1. 16S rRNA gene sequence based neighbor-joining phylogenetic tree of the bacterial strains isolated from the rhizosphere of Bolboschoenus maritimus.

Notes: GenBank accession numbers are given in brackets.

The bacterial strains of this study appear in bold. Only bootstrap values above $50 \%$ are shown (1000 replications). Bar, 2 substitutions per 100 nucleotide positions 


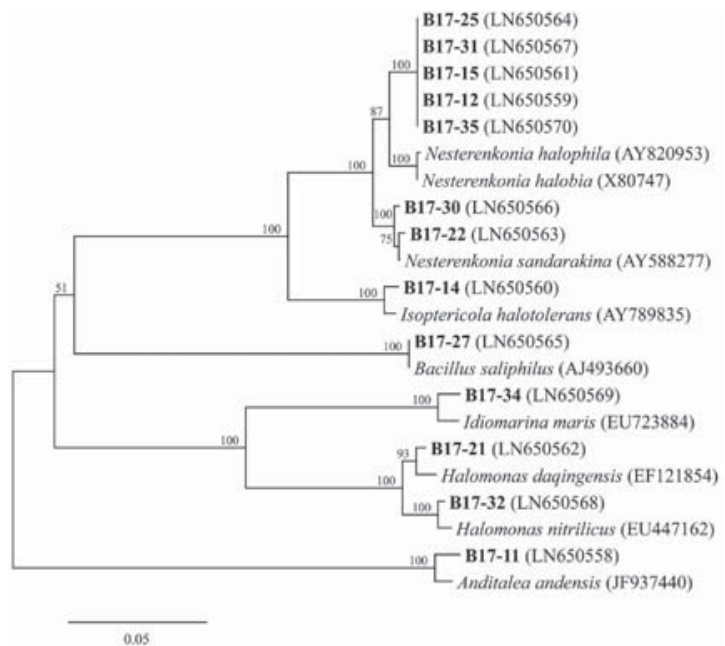

Figure 2. 16S rRNA gene sequence based neighbor-joining phylogenetic tree of the bacterial strains isolated from the rhizosphere of Puccinellia limosa.

Notes: GenBank accession numbers are given in brackets.

The bacterial strains of this study appear in bold. Only bootstrap values above $50 \%$ are shown (1000 replications). Bar, 5 substitutions per 100 nucleotide positions

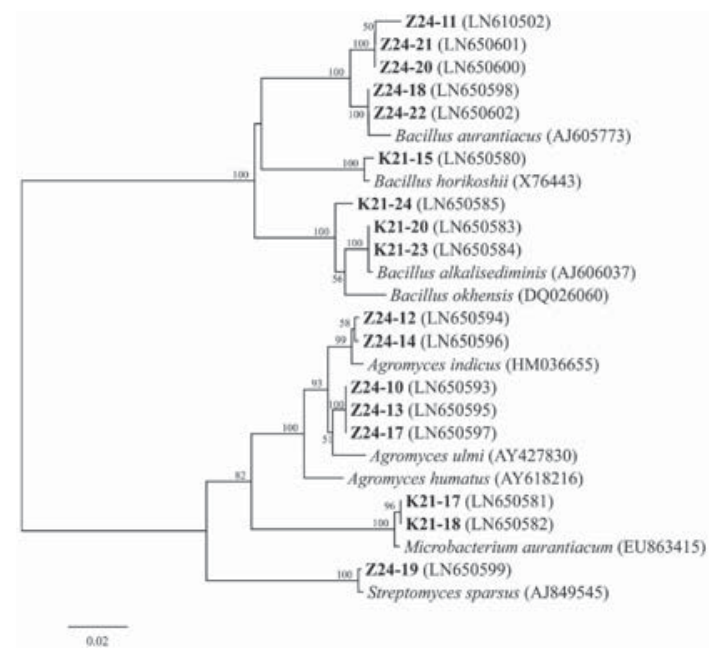

Figure 3. 16S rRNA gene sequence based neighbor-joining phylogenetic tree of the bacterial strains isolated from the rhizosphere of Aster tripolium.

Notes: GenBank accession numbers are given in brackets.

The bacterial strains of this study appear in bold. Only bootstrap values above $50 \%$ are shown (1000 replications). Bar, 2 substitutions per 100 nucleotide positions 


\section{Results and Discussion}

\section{Taxonomic diversity of bacterial strains}

From the rhizosphere of the studied three typical halophytes altogether 76 bacterial strains were isolated, and altogether 55 ARDRA representatives $(25,13$ and 17 among the Bolboschoenus, Puccinellia and Aster isolates) were sequenced (Figs 1-3). The strains were identified as members of genera Anaerobacillus, Bacillus and Exiguobacterium (Firmicutes), Agromyces, Isoptericola, Microbacterium, Micrococcus, Nocardiopsis, Nesterenkonia and Streptomyces (Actinobacteria), Halomonas and Idiomarina (Proteobacteria) and Anditalea (Bacteroidetes). From the samples representatives of 29 different bacterial species were revealed (Figs 1-3). However, some strains showed less than 97\% sequence similarities to described species, therefore they may represent new species. Regarding the number of identified species (19 from the DSMZ 940 and 18 from the modified DSMZ 830), the two media showed a similar degree of selectivity. Bacterial strains belonging to some Bacillus (e.g. B. alkalisediminis, B. pseudofirmus, B. horikoshii, B. saliphilus and B. aurantiacus) and Nesterenkonia (e.g. N. halophila and $N$. halobia) species as well as Micrococcus yunnanensis were isolated from both media.

Most of the Bolboschoenus rhizosphere isolates were related to different Bacillus species (Fig. 1). Representatives of Bacillus species are frequently isolated from different soda lakes and soils worldwide [10-16]. Several alkaliphilic and/or halophilic Bacillus species (e.g. B. alkalicola, B. alkalinitrilicus, B. bogoriensis, $B$. chagannorensis, $B$. daliensis, B. daqingensis, B. locisalis) were described from alkaline and/or saline lakes and soils [17-23], including the Hungarian soda ponds, as well. From the rhizosphere of Bolboschoenus surrounding all three studied soda ponds, besides representatives of $B$. horikoshii, B. pseudofirmus, B. saliphilus and B. safensis, a number of strains belonging to $B$. aurantiacus [24] and B. alkalisediminis [25] described from the sediment of Kiskunság soda ponds were recovered (Fig. 1). Two other strains which may represent novel taxa (Fig. 1), showed the highest sequence similarities to the strictly fermentative, aerotolerant and alkaliphilic species of Anaerobacillus alkalidiazotrophicus [26] described from a Mongolian soda soil and to the strictly anaerobic and obligate alkaliphilic species of Anaerobacillus alkalilacustris [27] described from the sediment of Khadyn soda lake (Russia). From the Bolboschoenus rhizosphere only one strain showed high sequence similarities to the alkaliphilic species of Exiguobacterium aurantiacum [28, 29].

Among the isolates from the Bolboschoenus rhizosphere, the phylum Actinobacteria was represented by strains closely related to Micrococcus yun- 
nanensis, Streptomyces rubrus and Nocardiopsis species (Fig. 1). The species of M. yunnanensis was recently described from surface-sterilized Polyspora axillaris roots [30]. Members of the genus Streptomyces are rarely isolated from soda lakes [12] but plant growth promoting activity of a Streptomyces isolate under saline soil conditions has been reported [31]. Representatives of the genus Nocardiopsis were isolated only from the rhizosphere of Bolboschoenus maritimus (Fig. 1), and were identified as $N$. lucentensis and $N$. exhalans. The latter species was detected also by cultivation from the shallow haloalkaline Lake Elmenteita, Kenya [12].

Members of different Halomonas species are also frequently isolated from soda lakes and soils [11-16]. In the rhizosphere of Bolboschoenus maritimus, strains identified as species of haloalkaliphilic H. kenyensis described from sediment samples of Kenyan soda lakes [32] and alkalitolerant and moderately halophilic $H$. boliviensis [33] described from a soil sample around the hypersaline lake Laguna Colorada (Bolivia) were found (Fig. 1).

The majority of the strains, isolated exclusively from the rhizosphere of Puccinellia limosa (Fig. 2), were related to moderately halophilic species of Nesterenkonia halobia [34], N. sandarakina [35] and N. halophila [36], described from ponds of a saltern located in Spain and from saline soil samples located in the eastern desert of Egypt and north-west China, respectively. In addition, strains affiliated with the recently described haloalkaliphilic Bacillus saliphilus [37], Isoptericola halotolerans [38], Idiomarina maris [39] as well as the moderately halophilic Halomonas daqingensis [40] and the haloalkaliphilic Halomonas nitrilicus [41] were identified (Fig. 2). Only one strain isolated also from the rhizosphere of Puccinellia limosa represented the phylum Bacteroidetes and was closely related to the alkaliphilic and halotolerant species of Anditalea andensis [42].

Members of different Agromyces species are among the bacteria usually detected by cultivation from various soil and rhizosphere samples. In a previous study, representatives of this genus were cultivated from the sediment of Zabszék soda pond [13]. In this study, all strains identified as Agromyces ulmi [43], A. humatus [44] and A. indicus [45] originated from the rhizosphere of Aster tripolum in the vicinity of Zab-szék soda pond (Fig. 3). Within the phylum Actinobacteria, strains representing species of Microbacterium aurantiacum and Streptomyces sparsus were also detected. Furthermore, strains belonging to alkaliphilic or alkalitolerant and moderately halophilic or halotolerant species of Bacillus alkalisediminis, B. aurantiacus, B. horikoshii and B. okhensis [46] were identified from the rhizosphere of Aster tripolum, as well (Fig. 3).

Based on the results of this study, the highest taxonomic diversity with 15 different species was revealed from the rhizosphere of Bolboschoenus mariti- 
mus. Although there was no substantial difference in the number of cultivated species among the sampling sites, their species composition was partly different.

Both the Bolboschoenus and Puccinellia rhizosphere samples originated from the shore of Böddi-szék soda pond and characterized with high $\mathrm{pH}$ and electric conductivity values [5] were dominated by representatives of Bacillus and Halomonas species. On the other hand, in the rhizosphere of Aster tripolum at Zab-szék soda pond where very low electric conductivity was detected [5], members of the genus Agromyces were typical. In contrast, members of the genus Nesterenkonia were cultivated only from the rhizosphere of Puccinellia limosa near the Böddi-szék soda pond where the highest electric conductivity was measured [5].

\section{Ecological tolerance of bacterial strains}

The $\mathrm{NaCl}$ and $\mathrm{pH}$ tolerance results of bacterial strains are presented in boxplot diagrams (Figs 4 and 5) according to the studied halophytes.

On the basis of the $\mathrm{NaCl}$ tolerance results, most strains were able to grow best in broths supplemented with 5,7 and $10 \% \mathrm{NaCl}$ (the highest $50^{\text {th }}$ percentiles), and less growth was observed in broths without $\mathrm{NaCl}$ and supplemented with 12 and $15 \% \mathrm{NaCl}$, regardless of the sample types (Fig. 4). However, substantial differences can be seen among the growth rate of bacterial strains. $\mathrm{NaCl}$ tolerance results of bacterial strains isolated from the Bolboschoenus rhizosphere are similar to those of the soda lakes and can be characterized with very small $\mathrm{H}$-spread values (the difference between the $75^{\text {th }}$ and $25^{\text {th }}$ percentiles) at $0 \%$ and $15 \% \mathrm{NaCl}$ concentrations and relatively large number of outside values at all $\mathrm{NaCl}$ concentrations (Fig. 4A). However, the H-spread values are the highest in case of Puccinellia rhizosphere isolates (Fig. 4B). Changes in salt concentration are the highest in the habitat of Puccinellia in accordance with the periodic wetting drying cycles which is reflected in the salt tolerance of bacterial strains. The widest salt tolerance (from $0 \%$ to $15 \% \mathrm{NaCl}$ concentrations) was also detected in case of strains isolated exclusively from the Puccinellia rhizosphere and identified as members of the genus Nesterenkonia. In contrast, the most uniform growth in broths with different $\mathrm{NaCl}$ concentrations and the lowest level of salt tolerance was detected in case of Aster rhizosphere isolates. In the boxplot diagram outside values are indicated almost exclusively at $0 \% \mathrm{NaCl}$ concentration (Fig. 4C).

Compared to the $\mathrm{NaCl}$ tolerance results, the growth of bacterial strains was balanced in the examined $\mathrm{pH}$ range in all three sample types (Fig. 5). This may be related to the fact that the $\mathrm{pH}$ value of the examined habitats is constantly alkaline regardless of the changes in salinity. Therefore, presence of facultative and 

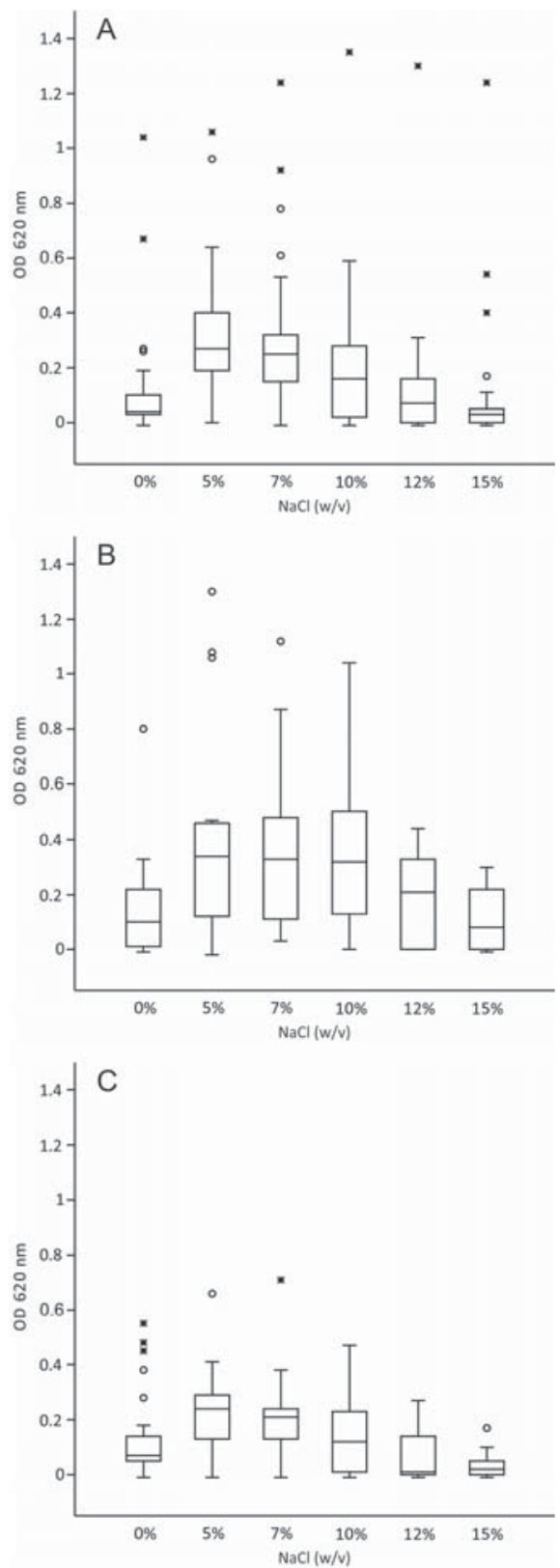

Figure 4. Boxplot diagrams of $\mathrm{NaCl}$ tolerance results of bacterial strains isolated from the rhizosphere of Bolboschoenus maritimus (A), Puccinellia limosa (B) and Aster tripolium (C).

(Bacterial growth at different $\mathrm{NaCl}$ concentrations was detected by the changes of optical density (OD) of the medium) 

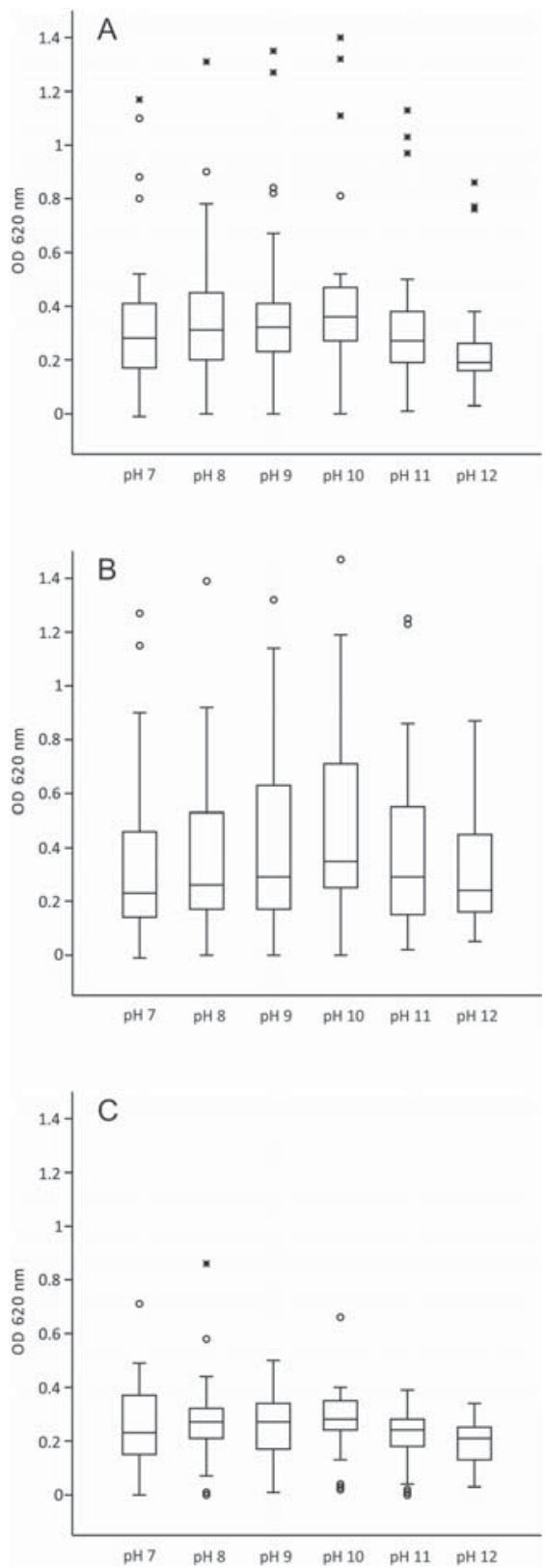

Figure 5. Boxplot diagrams of $\mathrm{pH}$ tolerance results of bacterial strains isolated from the rhizosphere of Bolboschoenus maritimus (A), Puccinellia limosa (B) and Aster tripolium (C).

(Bacterial growth at different $\mathrm{pH}$ values was detected by the changes of optical density (OD) of the medium) 
obligate alkaliphilic bacteria (e.g. Bacillus species) is typical. Nevertheless, similarly to the $\mathrm{NaCl}$ tolerance results, sample type characteristics (e.g. the highest number of the outlier points at the Bolboschoenus sample, the highest H-spread values at the Puccinellia sample) can be observed in the case of $\mathrm{pH}$ tolerance, as well.

\section{Conclusions}

Regardless of the media used for cultivation, most strains isolated from the rhizosphere of halophytes living nearby the Kiskunság soda ponds showed the highest $16 \mathrm{~S}$ rDNA sequence similarity to haloalkaliphilic bacterial species described from soda and saline lakes or soils in the recent years. Both bacterial species composition and ecological tolerance of bacterial strains were partly different in accordance with the difference in the physical and chemical properties of the studied rhizosphere samples.

\section{Acknowledgement}

This research was supported by the Hungarian Scientific Research Fund (OTKA) Grant K108572.

\section{Conflict of Interest}

None.

\section{References}

1. Tóth, T.: Salt-affected soils and their native vegetation in Hungary. In Öztürk, M., Böer, B., Barth, H.J., Breckle, S.W., Clüsener-Godt, M., Khan, M.A. (eds.): Sabkha Ecosystems, Tasks for Vegetation Science Vol. 46, Springer Science+Business Media B.V., 2011, pp. $113-132$.

2. Borhidi, A.: Social behaviour types, the naturalness and relative ecological indicator values of the higher plants in the Hungarian Flora. Acta Botanica Hungarica 39, 97-181 (1995).

3. Füzy, A., Tóth, T., Bíró, B.: Seasonal dynamics of mycorrhizal colonization in the rhizosphere of some dominant halophytes. Agrokémia és Talajtan 55, 231-240 (2006).

4. Füzy, A., Bíró, B., Tóth, T., Hildebrandt, U., Bothe, H.: Drought, but not salinity, determines the apparent effectiveness of halophytes colonized by arbuscular mycorrhizal fungi. J Plant Physiol 165, 1181-1192 (2008). 
5. Bárány, Á., Szili-Kovács, T., Krett, G., Füzy, A., Márialigeti, K., Borsodi, A.K.: Metabolic activity and genetic diversity of microbial communities inhabiting the rhizosphere of halophyton plants. Acta Microbiol Immunol Hung 61, 347-361 (2014).

6. Hammer, R., Harper, D.A.T., Ryan, P.D.: PAST: Paleontological statistics software package for education and data analysis. Palaeontologia Electronica 4(1), 9 (2001).

7. Massol-Deya, A.A., Odelson, D.A., Hickey, R.F., Tiedje, J.M.: Bacterial community fingerprinting of amplified $16 \mathrm{~S}$ and $16-23 \mathrm{~S}$ ribosomal DNA sequences and restriction endonuclease analysis (ARDRA). In: Akkermans, A.D.L., van Elsas, J.D., deBruijn, F.J. (eds): Molecular Microbial Ecology Manual. Kluwer Academic Publishers, Dordrecht, 1995, pp. 3.3.2:1-3.3.2:8

8. Kim, O.S., Cho, Y.J., Lee, K., Yoon, S.H., Kim, M., Na, H., Park, S.C., Jeon, Y.S., Lee, J.H., Yi, H., Won, S., Chun, J.: Introducing EzTaxon-e: A prokaryotic 16S rRNA Gene sequence database with phylotypes that represent uncultured species. Int J Syst Evol Microbiol 62, 716-721 (2012).

9. Tamura, K., Peterson, D., Peterson, N., Stecher, G., Nei, M., Kumar, S.: MEGA5: Molecular evolutionary genetics analysis using maximum likelihood, evolutionary distance, and maximum parsimony methods. Mol Biol Evol 28, 2731-2739 (2011).

10. Grant, W.D., Mwatha, W.E., Jones, B.E.: Alkaliphiles: ecology, diversity and application. FEMS Microbiol Rev 43, 260-296 (1990).

11. Zhang, W., Mao, W., Xue, Y., Ma, Y., Zhou, P.: Diversity of alkaliphilic bacteria in Hailer soda lakes, Inner Mongolia Autonomous Region of China (in Chinese). Biodivers Sci 9, 44-50 (2001).

12. Mwirichia, R., Muigai, A.W., Tindall, B., Boga, H.I., Stackebrandt, E.: Isolation and characterisation of bacteria from the haloalkaline Lake Elmenteita, Kenya. Extremophiles 14, 339-348 (2010).

13. Szabó, G., Borsodi, A., Vladár, P., Cech, G., Tóth, E., Boros, E., Márialigeti, K.: A Kiskunsági Nemzeti Park szikes tavainak bakteriológiai vizsgálata. Hidrol Közl 84, 147-150 (2004). (in Hungarian)

14. Borsodi, A.K., Vladár, P., Rusznyák, A., Szabó, G., Sipos, R., Márialigeti, K.: Tenyésztésen alapuló és tenyésztéstől független molekuláris biológiai vizsgálatok a Kiskunsági NP szikes tavainak baktériumközösségein. Hidrol Közl 85, 23-25 (2005) (in Hungarian).

15. Rusznyák, A., Szabó, G., Pollák, B., Vágány, V., Palatinszky, M.: Diversity of reed (Phragmites australis) stem biofilm bacterial communities in two Hungarian soda lakes. Acta Microbiol Immunol Hung 54, 339-352 (2007).

16. Rusznyák, A., Vladár, P., Szabó, G., Márialigeti K., Borsodi, A.K.: Phylogenetic and metabolic bacterial diversity of Phragmites australis periphyton communities in two Hungarian soda ponds. Extremophiles 12, 763-773 (2008).

17. Zhai, L., Ma, Y., Xue, Y., Ma, Y.: Bacillus alkalicola sp. nov., an alkaliphilic, Gram-positive bacterium isolated from Zhabuye lake in Tibet, China. Curr Microbiol 69, 311-316 (2014).

18. Sorokin, D.Y., van Pelt, S., Tourova, T.P.: Utilization of aliphatic nitriles under haloalkaline conditions by Bacillus alkalinitrilicus sp. nov. isolated from soda solonchak soil. FEMS Microbiol Lett 288, 235-240 (2008).

19. Vargas, V.A., Delgado, O.D., Hatti-Kaul, R., Mattiasson, B.: Bacillus bogoriensis sp. nov., a novel alkaliphilic, halotolerant bacterium isolated from a Kenyan soda lake. Int J Syst Evol Microbiol 55, 899-902 (2005). 
20. Carrasco, I.J., Márquez, M.C., Xue, Y., Ma, Y., Cowan, D.A., Jones, B.E., Grant, W.D., Ventosa, A.: Bacillus chagannorensis sp. nov., a moderate halophile from a soda lake in Inner Mongolia, China. Int J Syst Evol Microbiol 57, 2084-2088 (2007).

21. Zhai, L., Liao, T., Xue, Y., Ma, Y.: Bacillus daliensis sp. nov., an alkaliphilic, Gram-positive bacterium isolated from a soda lake. Int J Syst Evol Microbiol 62, 949-953 (2012).

22. Wang, S., Sun, L., Wei, D., Zhou, B., Zhang, J., Gu, X., Zhang, L., Liu, Y., Li, Y., Guo, W., Jiang, S., Pan, Y., Wang, Y.: Bacillus daqingensis sp. nov., a halophilic, alkaliphilic bacterium isolated fromSaline-sodic soil in Daqing, China. J Microbiol 52, 548-553 (2014).

23. Márquez, M.C., Carrasco, I.J., de la Haba, R.R., Jones, B.E., Grant, W.D., Ventosa, A.: Bacillus locisalis sp. nov., a new haloalkaliphilic species from hypersaline and alkaline lakes of China, Kenya and Tanzania. Syst Appl Microbiol 34, 424-428 (2011).

24. Borsodi, A.K., Márialigeti, K., Szabó, G., Palatinszky, M., Pollák, B., Kéki, Zs., Kovács, A.L., Schumann, P., Tóth, E.M.: Bacillus aurantiacus sp. nov., an alkaliphilic and moderately halophilic bacterium isolated from Hungarian soda lakes. Int J Syst Evol Microbiol 58, 845-885 (2008).

25. Borsodi, A.K., Pollák, B., Kéki, Zs., Rusznyák, A., Kovács, A.L., Spröer, C., Schumann, P., Márialigeti, K., Tóth, E.M.: Bacillus alkalisediminis sp. nov., an alkaliphilic and moderately halophilic bacterium isolated from sediment of extremely shallow soda ponds. Int J Syst Evol Microbiol 61, 1880-1886 (2011).

26. Sorokin, I.D., Kravchenko, I.K., Tourova, T.P., Kolganova, T.V., Boulygina, E.S., Sorokin, D.Y.: Bacillus alkalidiazotrophicus sp. nov., a diazotrophic, low salt-tolerant alkaliphile isolated from Mongolian soda soil. Int J Syst Evol Microbiol 58, 2459-2464 (2008).

27. Zavarzina, D.G., Tourova, T.P., Kolganova, T.V., Boulygina, E.S., Zhilina, T.N.: Description of Anaerobacillus alkalilacustre gen. nov., sp. nov. - Strictly anaerobic diazotrophic bacillus isolated from soda lake and transfer of Bacillus arseniciselenatis, Bacillus macyae, and Bacillus alkalidiazotrophicus to Anaerobacillus as the new combinations A. arseniciselenatis comb. nov., A. macyae comb. nov., and $A$. alkalidiazotrophicus comb. nov. Microbiology 78, 723-731 (2009).

28. Collins, M.D., Lund, B.M., Farrow, J.A.E., Schleifer, K.H.: Chemotaxonomic study of an alkalophilic bacterium, Exiguobacterium aurantiacum gen. nov., sp. nov. Microbiology 129, 2037-2042 (1983).

29. Frühling, A., Schumann, P., Hippe, H., Sträubler, B., Stackebrandt, E.: Exiguobacterium undae sp. nov. and Exiguobacterium antarcticum sp. nov. Int J Syst Evol Microbiol 52, 1171-1176 (2002).

30. Zhao, G.Z., Li, J., Qin, S., Zhang, Y.Q., Zhu, W.Y., Jiang, C.L., Xu, L.H., Li, W.J.: Micrococcus yunnanensis sp. nov., a novel actinobacterium isolated from surface-sterilized Polyspora axillaris roots. Int J Syst Evol Microbiol 59, 2383-2387 (2009).

31. Sadeghi, A., Karimi, E., Dahaji, P.A., Javid, M.G., Dalvand, Y., Askari, H.: Plant growth promoting activity of an auxin and siderophore producing isolate of Streptomyces under saline soil conditions. World J Microbiol Biotechnol 28, 1503-1509 (2012).

32. Boltyanskaya, Y.V., Kevbrin, V.V., Lysenko, A.M., Kolganova, T.V., Tourova, T.P., Osipov, G.A., Zhilina, T.N.: Halomonas mongoliensis sp. nov. and Halomonas kenyensis sp. nov., new haloalkaliphilic denitrifiers capable of $\mathrm{N}_{2} \mathrm{O}$ reduction, isolated from soda lakes. Microbiology 76, 739-747 (2007).

33. Quillaguamán, J., Hatti-Kaul, R., Mattiasson, B., Alvarez, M.T., Delgado, O.: Halomonas boliviensis sp. nov., an alkalitolerant, moderate halophile isolated from soil around a Bolivian hypersaline lake. Int J Syst Evol Microbiol 54, 721-725 (2004). 
34. Mota, R.R., Márquez, M.C., Arahal, D.R., Mellado, E., Ventosa, A.: Polyphasic taxonomy of Nesterenkonia halobia. Int J Syst Bacteriol 47, 1231-1235 (1997).

35. Li, W.J., Chen, H.H., Kim, C.J., Zhang, Y.Q., Park, D.J., Lee, J.C., Xu, L.H., Jiang, C.L.: Nesterenkonia sandarakina sp. nov. and Nesterenkonia lutea sp. nov., novel actinobacteria, and emended description of the genus Nesterenkonia. Int J Syst Evol Microbiol 55, 463-466 (2005).

36. Li, W.J., Zhang, Y.Q., Schumann, P., Liu, H.Y., Yu, L.Y., Zhang, Y.Q., Stackebrandt, E., Xu, L.H., Jiang, C.L.: Nesterenkonia halophila sp. nov., a moderately halophilic, alkalitolerant actinobacterium isolated from a saline soil. Int J Syst Evol Microbiol 58, 1359-1363 (2008).

37. Romano, I., Lama, L., Nicolaus, B., Gambacorta, A., Giordano, A.: Bacillus saliphilus sp. nov., isolated from a mineral pool in Campania, Italy. Int J Syst Evol Microbiol 55, 159163 (2005).

38. Zhang, Y.Q., Schumann, P., Li, W.J., Chen, G.Z., Tian, X.P., Stackebrandt, E., Xu, L.H., Jiang, C.L.: Isoptericola halotolerans sp. nov., a novel actinobacterium isolated from saline soil from Qinghai Province, north-west China. Int J Syst Evol Microbiol 55, 18671870 (2005).

39. Zhang, Y.J., Zhang, X.Y., Zhao, H.L., Zhou, M.Y., Li, H.J., Gao, Z.M., Chen, X.L., Dang, H.Y., Zhang, Y.Z.: Idiomarina maris sp. nov., a marine bacterium isolated from sediment. Int J Syst Evol Microbiol 62, 370-375 (2012).

40. Wu, G., Wu, X.Q., Wang, Y.N., Chi, C.Q., Tang, Y.Q., Kida, K., Wu, X.L., Luan, Z.K.: Halomonas daqingensis sp. nov., a moderately halophilic bacterium isolated from an oilfield soil. Int J Syst Evol Microbiol 58, 2859-2865 (2008).

41. Chmura, A., Shapovalova, A.A., van Pelt, S., van Rantwijk, F., Tourova, T.P., Muyzer, G., Sorokin, D.Y.: Utilization of arylaliphatic nitriles by haloalkaliphilic Halomonas nitrilicus sp. nov. isolated from soda soils. Appl Microbiol Biotechnol 81, 371-378 (2008).

42. Shi, W., Takano, T., Liu, S.: Anditalea andensis gen. nov., sp. nov., an alkaliphilic, halotolerant bacterium isolated from extreme alkali-saline soil. Antonie van Leeuwenhoek 102, 703-710 (2012).

43. Rivas, R., Trujillo, M.E., Mateos, P.F., Martínez-Molina, E., Velázquez, E.: Agromyces ulmi sp. nov., a xylanolytic bacterium isolated from Ulmus nigra in Spain. Int J Syst Evol Microbiol 54, 1987-1990 (2004).

44. Jurado, V., Groth, I., Gonzalez, J.M., Laiz, L., Schuetze, B., Saiz-Jimenez, C.: Agromyces italicus sp. nov., Agromyces humatus sp. nov. and Agromyces lapidis sp. nov., isolated from Roman catacombs. Int J Syst Evol Microbiol 55, 871-875 (2005).

45. Dastager, S.G., Qiang, Z.L., Damare, S., Tang, S.K., Li, W.J.: Agromyces indicus sp. nov., isolated from mangroves sediment in Chorao Island, Goa, India. Antonie van Leeuwenhoek 102, 345-352 (2012).

46. Nowlan, B., Dodia, M.S., Singh, S.P., Patel, B.K.C.: Bacillus okhensis sp. nov., a halotolerant and alkalitolerant bacterium from an Indian saltpan. Int J Syst Evol Microbiol 56, 1073-1077 (2006). 